Marquette University

e-Publications@Marquette

Chemistry Faculty Research and Publications

Chemistry, Department of

8-8-2015

\title{
Di- and Trinuclear Mixed-Valence Copper Amidinate Complexes from Reduction of Iodine
}

Andrew C. Lane

University of Missouri

Charles L. Barnes

University of Missouri

William E. Antholine

Medical College of Wisconsin

Denan Wang

Marquette University, denan.wang@marquette.edu

Adam T. Fiedler

Marquette University, adam.fiedler@marquette.edu

See next page for additional authors

Accepted version. Inorganic Chemistry, Vol 54, No. 17 (August 8, 2015): 8509-8517. DOI. (C) 2015 American Chemical Society. Used with permission. 
Authors

Andrew C. Lane, Charles L. Barnes, William E. Antholine, Denan Wang, Adam T. Fiedler, and Justin R. Walensky 


\title{
Di- and Trinuclear Mixed-Valence Copper Amidinate Complexes from Reduction of Iodine
}

\author{
Andrew C. Lane \\ Department of Chemistry, University of Missouri, \\ Columbia, MO \\ Charles L. Barnes \\ Department of Chemistry, University of Missouri, \\ Columbia, MO \\ William E. Antholine \\ Department of Biophysics, Medical College of Wisconsin, \\ Milwaukee, WI \\ Denan Wang \\ Department of Chemistry, Marquette University, \\ Milwaukee, WI \\ Adam T. Fiedler \\ Department of Chemistry, Marquette University, \\ Milwaukee, WI \\ Justine R. Walensky \\ Department of Chemistry, University of Missouri, \\ Columbia, MO
}




\begin{abstract}
Molecular examples of mixed-valence copper complexes through chemical oxidation are rare but invoked in the mechanism of substrate activation, especially oxygen, in copper-containing enzymes. To examine the cooperative chemistry between two metals in close proximity to each other we have begun to study the reactivity of a dinuclear $\mathrm{Cu}(\mathrm{I})$ amidinate complex. The reaction of $\left[\left(2,6-\mathrm{Me}_{2} \mathrm{C}_{6} \mathrm{H}_{3} \mathrm{~N}\right)_{2} \mathrm{C}(\mathrm{H})\right]_{2} \mathrm{Cu}_{2}, \mathbf{1}$, with $\mathrm{I}_{2}$ in $\mathrm{THF}, \mathrm{CH}_{3} \mathrm{CN}$, and toluene affords three new mixed-valence copper complexes, $[(2,6-$ $\left.\left.\mathrm{Me}_{2} \mathrm{C}_{6} \mathrm{H}_{3} \mathrm{~N}\right)_{2} \mathrm{C}(\mathrm{H})\right]_{2} \mathrm{Cu}_{2}\left(\mu_{2}-\mathrm{I}_{3}\right)(\mathrm{THF})_{2}, 2$, $\left[\left(2,6-\mathrm{Me}_{2} \mathrm{C}_{6} \mathrm{H}_{3} \mathrm{~N}\right)_{2} \mathrm{C}(\mathrm{H})\right]_{2} \mathrm{Cu}_{2}\left(\mu_{2}-\right.$ I) $(\mathrm{NCMe})_{2}, \mathbf{3}$, and $\left[\left(2,6-\mathrm{Me}_{2} \mathrm{C}_{6} \mathrm{H}_{3} \mathrm{~N}\right)_{2} \mathrm{C}(\mathrm{H})\right]_{3} \mathrm{Cu}_{3}\left(\mu_{3}-\mathrm{I}\right)_{2}, 4$, respectively. The first two compounds have been characterized by UV-Vis and EPR spectroscopy and their molecular structure determined by X-ray crystallography. Both di- and trinuclear mixed-valence intermediates have been characterized for the reaction of compound $\mathbf{1}$ to compound $\mathbf{4}$ and the molecular structure of $\mathbf{4}$ has been determined by X-ray crystallography. The electronic structure of each of these complexes has also been investigated using density functional theory.
\end{abstract}

\title{
Introduction
}

Copper-containing enzymes play a central role in the activation of small molecules such as $\mathrm{O}_{2}$ and $\mathrm{N}_{2} \mathrm{O}, 1$ hence elucidating new possibilities for metal-mediated small molecule activation through synthetic models is one approach to understanding their enzymatic activity. Even though a mixed-valence state is invoked in the mechanism of several copper-containing enzymes such as nitrous oxide reductase, $, \underline{2}, \underline{3}$ cytochrome $c$ oxidase,,$\underline{4, \underline{5}}$ and hemocyanin, $\underline{6}$ few molecular examples of mixed-valence copper complexes have been isolated. Synthetically, this is typically done by self-assembly, ${ }^{\underline{7}-\underline{22}}$ electrochemically, $\underline{23}, \underline{24}$ and, less commonly, by chemical redox. $\underline{25}-\underline{32}$ Additionally, mixed-valence $\mathrm{Cu}$ coordination polymers are prevalent. $\underline{3}-$ 36 The use of nitrogen-donor ligands for modeling Cu-containing enyzmes is well-established leading to mechanistic details, especially for monometallic copper complexes. $\frac{37}{}$ For example, the interaction of $\mathrm{Cu}(\mathrm{I})$ and $\mathrm{O}_{2}$ with $\beta$-diketiminate ligands has been shown to involve an oxidation of $\mathrm{Cu}(\mathrm{I})$ to $\mathrm{Cu}(\mathrm{II})$ with concomitant one-electron reduction of $\mathrm{O}_{2}$ to the superoxide, $\mathrm{O}_{2}^{-.38}$ Finally, the Karlin group has many examples of $\mathrm{O}_{2}$ activation with dinuclear $\mathrm{Cu}(\mathrm{I})$ complexes for modeling multinuclear copper clusters that catalyze oxidase reactions. $\underline{39}$

The $\mathrm{Cu}_{\mathrm{A}}$ site of cytochrome $c$ oxidase contains two fourcoordinate copper ions, bridging dithiolates, approximately $2.6 \AA$ apart, and has mixed-valence $2 \mathrm{Cu}(1.5,1.5)$ resting state. Copper(I) amidinate complexes $\stackrel{40,41}{ }$ feature two copper(I) ions with a similar Cu$\mathrm{Cu}$ separation and have two nitrogen atoms coordinated similar to the 
$\mathrm{Cu}_{\mathrm{A}}$ site which has a nitrogen from histidine coordinated to each copper, Figure 1 . The reactivity of bimetallic $\mathrm{Cu}(\mathrm{I})$ amidinate complexes is virtually unknown and our objective was to expand on the chemistry of a dinuclear $\mathrm{Cu}(\mathrm{I})$ complex, $[(2,6-$

$\left.\left.\mathrm{Me}_{2} \mathrm{C}_{6} \mathrm{H}_{3} \mathrm{~N}\right)_{2} \mathrm{C}(\mathrm{H})\right]_{2} \mathrm{Cu}_{2}, \mathbf{1}$, we recently reported. $\underline{42}$ One mixed-valence copper amidinate complex has been reported. ${ }^{7 f}$ Based on $\mathbf{1}$, we herein report the synthesis and characterization of three new mixed-valence copper complexes simply from reactivity differences in polar (THF and $\mathrm{NCCH}_{3}$ ) and nonpolar (toluene) solvents. The reactions with $\mathbf{1}$ and $\mathrm{I}_{2}$ in THF and $\mathrm{NCCH}_{3}$ have similar electronic structure to the $\mathrm{Cu}_{\mathrm{A}}$ site.

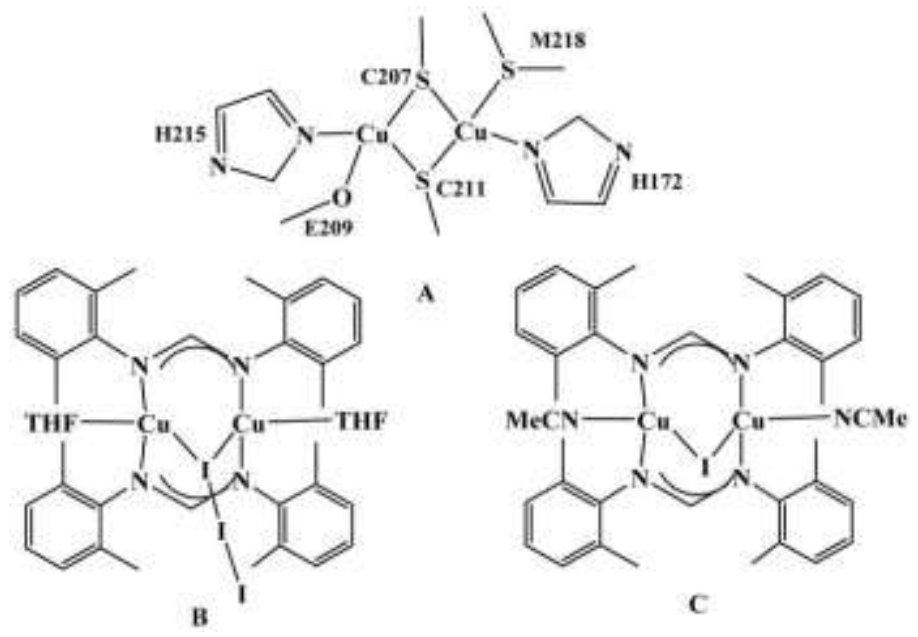

Figure 1. (A) Rudimentary illustration of $\mathrm{Cu}_{A}$ site of cytochrome $c$ oxidase; (B) and (C) Mixed-valence copper amidinate complexes presented in this work.

\section{Experimental Section}

\section{General considerations}

All manipulations were carried out inside an argon or nitrogen atmosphere Vacuum Atmosphere OMNI glove box with rigorous exclusion of air and water unless otherwise specified. Anhydrous solvents (Aldrich) were purchased, spared with nitrogen, and stored over molecular sieves. [Cu(NCMe) $\left.{ }_{4}\right] \mathrm{PF}_{6}$ (Strem) was used as received. $\mathrm{I}_{2}$ (Aldrich) was sublimed prior to use. $\mathrm{Cu}_{2}\left[\left(2,6-\mathrm{Me}_{2} \mathrm{C}_{6} \mathrm{H}_{3} \mathrm{~N}\right)_{2} \mathrm{C}(\mathrm{H})\right]_{2}, \mathbf{1}$,

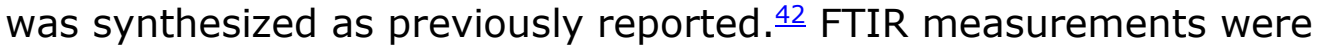
made on a Thermo-Nicolet instrument using spectroscopic grade $\mathrm{KBr}$. The UV-Vis-NIR measurements were collected with a Cary 5000 instrument. Solid-state Raman measurements were obtained on a 
Renishaw InVia spectrometer at an excitation wavelength of $632.8 \mathrm{~nm}$. Elemental analysis was performed by Atlantic Microlab, Inc. (Norcross, GA).

\section{Synthesis of $\left[\left(2,6-\mathrm{Me}_{2} \mathrm{C}_{6} \mathrm{H}_{3} \mathrm{~N}\right)_{2} \mathrm{C}(\mathrm{H})\right]_{2} \mathrm{Cu}_{2}\left(\mu_{2}-\mathrm{I}_{3}\right)(\mathrm{THF})_{2}, 2$}

In a scintillation vial, 1 (100 $\mathrm{mg}, 0.16 \mathrm{mmol})$ was dissolved in THF $(10 \mathrm{~mL})$ and $\mathrm{I}_{2}(40 \mathrm{mg}, 0.16 \mathrm{mmol})$ was added at room temperature. The solution color immediately changed from colorless to dark brown-red. After $4 \mathrm{~h}$, the solvent was removed under vacuum to yield a dark brown-red powder (90 mg, 56\%). Anal. Calcd. For $\mathrm{Cu}_{2} \mathrm{C}_{42} \mathrm{H}_{54} \mathrm{I}_{3} \mathrm{~N}_{4} \mathrm{O}_{2}$ : C, 43.69\%; $\mathrm{H}, 4.71 \% ; \mathrm{N}, 4.85 \%$. Found: C, 43.65\%; $\mathrm{H}, 4.32 \%$; N, 4.69\%. X-ray quality crystals were grown overnight from a saturated THF solution at $-25^{\circ} \mathrm{C}$. UV-Vis-NIR (0.97 mM, THF): 530 $\mathrm{nm}\left(\varepsilon=2250 \mathrm{M}^{-1} \mathrm{~cm}^{-1}\right), 1100 \mathrm{~nm}\left(\varepsilon=200 \mathrm{M}^{-1} \mathrm{~cm}^{-1}\right), 1940 \mathrm{~nm}(\varepsilon=$ $500 \mathrm{M}^{-1} \mathrm{~cm}^{-1}$ ). IR (KBr): 3321 (w), 2966 (w), 2908 (w), 2157 (s), 1646 (s), $1585(\mathrm{~m}), 1458(\mathrm{~m}), 1298(\mathrm{~m}), 1184(\mathrm{~m}), 1086(\mathrm{~m}), 755$ (m).

\section{Synthesis of $\left[\left(2,6-\mathrm{Me}_{2} \mathrm{C}_{6} \mathrm{H}_{3} \mathrm{~N}\right)_{2} \mathrm{C}(\mathrm{H})\right]_{2} \mathrm{Cu}_{2}\left(\mu_{2}-\mathrm{I}\right)(\mathrm{NCMe})_{2}$, 3}

In a scintillation vial, $1(100 \mathrm{mg}, 0.16 \mathrm{mmol})$ was dissolved in acetonitrile $(15 \mathrm{~mL})$ and $\mathrm{I}_{2}(40 \mathrm{mg}, 0.16 \mathrm{mmol})$ was added at room temperature. The solution color immediately changed from colorless to dark red. After $4 \mathrm{~h}$, the solvent was removed under vacuum to yield a dark red-brown powder ( $96 \mathrm{mg}, 71 \%$ ). Anal. Calcd for $\mathrm{Cu}_{2} \mathrm{C}_{38} \mathrm{H}_{44} \mathrm{IN}_{6}$ : C, 54.41\%; H, 5.29\%; N, 10.02\%. Found: C, 54.25\%; H, 5.37\%; N, 9.88\%. X-ray quality crystals were grown overnight from a saturated acetonitrile solution at $-25^{\circ} \mathrm{C}$. UV-Vis-NIR $\left(0.88 \mathrm{mM}, \mathrm{NCCH}_{3}\right): 500$ (sh) $\mathrm{nm}\left(1600 \mathrm{M}^{-1} \mathrm{~cm}^{-1}\right), 860 \mathrm{~nm}\left(\varepsilon=500 \mathrm{M}^{-1} \mathrm{~cm}^{-1}\right), 1510 \mathrm{~nm}(\varepsilon=$ $\left.250 \mathrm{M}^{-1} \mathrm{~cm}^{-1}\right)$. IR (KBr): $3051(\mathrm{w}), 2937(\mathrm{w}), 2908(\mathrm{w}), 2153(\mathrm{~m})$, $1638(\mathrm{~m}), 1564(\mathrm{~s}), 1470(\mathrm{~s}), 1323(\mathrm{~s}), 1254(\mathrm{~m}), 1196(\mathrm{~s}), 1089$ $(\mathrm{m}), 767(\mathrm{~s})$.

\section{Synthesis of $\left[\left(2,6-\mathrm{Me}_{2} \mathrm{C}_{6} \mathrm{H}_{3} \mathrm{~N}\right)_{2} \mathrm{C}(\mathrm{H})\right]_{3} \mathrm{Cu}_{3}\left(\mu_{3}-\mathrm{I}\right)_{2}, 4$}

In a scintillation vial, $1(100 \mathrm{mg}, 0.16 \mathrm{mmol})$ was dissolved in toluene $(10 \mathrm{~mL})$ and $\mathrm{I}_{2}(40 \mathrm{mg}, 0.16 \mathrm{mmol})$ was added at room 
temperature. The solution color immediately changed from colorless to dark brown-red. After $4 \mathrm{~h}$, the solvent was removed under vacuum to yield a dark brown powder (96 mg, 50\%). Anal. Calcd. for $\mathrm{Cu}_{3} \mathrm{C}_{58} \mathrm{H}_{65} \mathrm{I}_{2} \mathrm{~N}_{6}$ : C, 53.98\%; H, 5.08\%; N, 6.51\%. Found: C, 54.37\%; $\mathrm{H}, 4.75 \% ; \mathrm{N}, 6.34 \%$. X-ray quality crystals were grown overnight from a saturated toluene solution at $-25^{\circ} \mathrm{C}$. UV-Vis-NIR $(1.05 \mathrm{mM}$, toluene): $480(\mathrm{sh}) \mathrm{nm}\left(\varepsilon=1000 \mathrm{M}^{-1} \mathrm{~cm}^{-1}\right), 680 \mathrm{~nm}\left(\varepsilon=250 \mathrm{M}^{-1}\right.$ $\left.\mathrm{cm}^{-1}\right)$. IR (KBr): $3019(\mathrm{w}), 2944(\mathrm{~m}), 2914(\mathrm{~m}), 2155(\mathrm{~m}), 1646(\mathrm{~m})$, $1564(\mathrm{~m}) 1467(\mathrm{~m}), 1194(\mathrm{~m}), 1091(\mathrm{~m}), 1029(\mathrm{w}), 763(\mathrm{~m})$.

\section{Crystal structure determination and refinement}

The selected single crystal of 2-4 was mounted on a nylon cryoloop using viscous hydrocarbon oil. X-ray data collection was performed at $100(2)$ or $173(2) \mathrm{K}$. The X-ray data were collected on a Bruker CCD diffractometer with monochromated Mo-Ka radiation $(\lambda=$ $0.71073 \AA$ ). The data collection and processing utilized Bruker Apex 2 suite of programs. $\underline{43}$ The structures were solved using direct methods and refined by full-matrix least-squares methods on $F^{2}$ using Bruker SHELX-97 program. $\frac{44}{}$ All non-hydrogen atoms were refined with anisotropic displacement parameters. All hydrogen atoms were placed at calculated positions and included in the refinement using a riding model. Thermal ellipsoid plots were prepared by using X-seed $\underline{45}$ with 30 or $50 \%$ of probability displacements for non-hydrogen atoms. Crystal data and details for data collection for complexes 2-4 are also provided in Table 1.

Table 1. X-ray crystallographic data for complexes 2 - 4.

$\begin{array}{lccc} & \mathbf{2 \bullet 2 T H F} & \mathbf{3} & \mathbf{4} \cdot \mathbf{C}_{\mathbf{7}} \mathbf{H}_{\mathbf{8}} \\ \text { CCDC Deposit } & 893748 & 1400878 & 893747 \\ \text { Number } & & & \\ \text { Empirical Formula } & \mathrm{Cu}_{2} \mathrm{C}_{50} \mathrm{H}_{70} \mathrm{I}_{3} \mathrm{~N}_{4} \mathrm{O}_{4} & \mathrm{Cu}_{2} \mathrm{C}_{38} \mathrm{H}_{44} \mathrm{IN}_{6} & \mathrm{Cu}_{3} \mathrm{C}_{58} \mathrm{H}_{65} \mathrm{I}_{2} \mathrm{~N}_{6} \\ \text { Formula weight } & 1298.88 & 838.77 & 1290.58 \\ \text { ( } \mathrm{g} / \text { mol) } & & & \\ \text { Crystal Habit, color } & \text { plate, brown-red } & \text { plate, red } & \text { plate, brown-purple } \\ \text { Temperature }(\mathrm{K}) & 173(2) & 100(2) & 173(2) \\ \text { Space group } & P 2_{1} / \mathrm{n} & P 2_{1} / \mathrm{c} & P \text { na2 } 2_{1} \\ \text { Crystal system } & \text { Monoclinic } & \text { Monoclinic } & \text { Orthorhombic } \\ \text { Volume }\left(\AA^{3}\right) & 5300.3(5) & 3736.1(6) & 5475.2(17) \\ a(\AA) & 11.0680(6) & 10.9071(10) & 26.456(5) \\ b(\AA) & 15.4780(8) & 22.984(2) & 24.908(5)\end{array}$

Inorganic Chemistry, Vol 54, No. 17 (August 8, 2015): pg. 8509-8517. DOI. This article is @ American Chemical Society and permission has been granted for this version to appear in e-Publications@Marquette. American Chemical Society does not grant permission for this article to be further copied/distributed or hosted elsewhere without the express permission from American Chemical Society. 
NOT THE PUBLISHED VERSION; this is the author's final, peer-reviewed manuscript. The published version may be accessed by following the link in the citation at the bottom of the page.

2•2THF

$c(\AA)$

$a\left({ }^{\circ}\right)$

$\beta\left({ }^{\circ}\right)$

$Y\left({ }^{\circ}\right)$

$Z$

Calculated density

$\left(\mathrm{Mg} / \mathrm{m}^{3}\right)$

Absorption coefficient $\left(\mathrm{mm}^{-1}\right)$

Final $R$ indices $[\mathrm{I}>$ $2 \sigma(\mathrm{I})]$
30.9839(17)

90

93.0530(10)

90

4

1.628

2.594

$\mathrm{R} 1=0.0392, \mathrm{wR} 2=$ 0.0485
3

15.0298(13)

90

$97.4430(10)$

90

4

1.491

1.999

$R 1=0.0218, w R 2$

$=0.0522$ $\mathbf{4} \bullet \mathbf{C}_{7} \mathbf{H}_{8}$

$8.3089(15)$

90

90

90

4

1.566

\section{EPR Spectroscopy}

Most X-band EPR spectra at $110 \mathrm{~K}$ were obtained with a Bruker EMX spectrometer located at the National Biomedical EPR Center at the Medical College of Wisconsin. Spectra were simulated with EasySpin. $\frac{46}{}$ Additional X-band spectra were obtained at $10 \mathrm{~K}$ with an Elexsys E500 EPR spectrometer, Bruker, Billerica, MA. Q-band spectra were obtained on a Varian E109 spectrometer. Low frequency spectra (S-band $(3.5 \mathrm{GHz}$ ) and L-band $(2.0 \mathrm{GHz}$ ) were obtained using home built bridges and resonators at the National Biomedical EPR Center.

\section{DFT Calculations}

DFT calculations were performed using the ORCA 2.9 software package developed by Neese (MPI for Chemical Energy Conversion). $\underline{47}$ The computational models were derived from the crystallographic coordinates, although the methyl substituents at the 2- and 6positions of the phenyl rings were replaced by hydrogen atoms which were added by assuming idealized $\mathrm{C}-\mathrm{H}$ bond lengths and angles. The calculations utilized Becke's three-parameter hybrid functional for exchange along with the Lee-Yang-Parr correlation functional (B3LYP). ${ }^{48,49}$ Ahlrichs' valence triple- $\zeta$ basis set (TZV), in conjunction with the $\mathrm{TZV} / \mathrm{J}$ auxiliary basis set, $\underline{50,51}$ were used for the nonmetallic atoms; the "core properties" with extended polarization [CP(PPP)] basis set $\underline{52}$ was used for the $\mathrm{Cu}$ atoms. The contribution of spin-orbit coupling to the $\mathbf{g}$ - and A-tensors was evaluated by solving the coupled-perturbed self-consistent field (CP-SCF) equations. $\underline{53}-\underline{56}$ To ensure the accuracy of the hyperfine coupling constants, a high 
resolution grid with an integration accuracy of 7.0 was generated for the $\mathrm{Cu}$ atoms. Isosurface plots of molecular orbitals were prepared with the gOpenMol program 57 developed by Laaksonen. TD-DFT calculations $\underline{58}-\underline{60}$ computed absorption energies and intensities using the Tamm-Dancoff approximation. $\underline{61,62}$

\section{Results and Discussion}

We began exploring the reactivity of $\mathbf{1}$ to compare with the $\mathrm{Au}(\mathrm{I})$ analog, i.e. $\mathrm{Au}_{2}(\mathrm{amid})_{2} \cdot \frac{63}{}$ While the reaction of $\mathrm{Au}_{2}$ (amid) 2 with $\mathrm{I}_{2}$ produced a green product, $\mathrm{Au}_{2}$ (amid) ${ }_{2} \mathrm{I}_{2}$, containing two $\mathrm{Au}$ (II) centers, 1 with $\mathrm{I}_{2}$ in THF produces a dark red-brown solution, eq 1 . The ${ }^{1} \mathrm{H}$ NMR spectrum showed broad resonances indicating a paramagnetic species but no other conclusions could be drawn. The UV-Vis-NIR spectrum showed an absorption in the visible region at $530 \mathrm{~nm}$ (Figure S1). Absorptions at 1100 and $1940 \mathrm{~nm}$ are observed for $\mathbf{2}$ in the nearinfrared region (Figure S1). Dark red-brown crystals suitable for X-ray crystallography analysis were obtained from a saturated THF solution at $-35{ }^{\circ} \mathrm{C}$ definitively identifying the product as $[(2,6-$ $\left.\left.\mathrm{Me}_{2} \mathrm{C}_{6} \mathrm{H}_{3} \mathrm{~N}\right)_{2} \mathrm{C}(\mathrm{H})\right]_{2} \mathrm{Cu}_{2}\left(\mu_{2}-\mathrm{I}_{3}\right)(\mathrm{THF})_{2}, \mathbf{2}$, Figure 1. Complex 2 is the oneelectron reduction of $\mathrm{I}_{2}$ to $\mathrm{I}_{3}{ }^{-}$which bridges the two $\mathrm{Cu}$ metals and one THF solvent molecule coordinates to each metal as well. Based on formal valence, one metal must be $\mathrm{Cu}(\mathrm{I})$ and the other $\mathrm{Cu}(\mathrm{II})$.

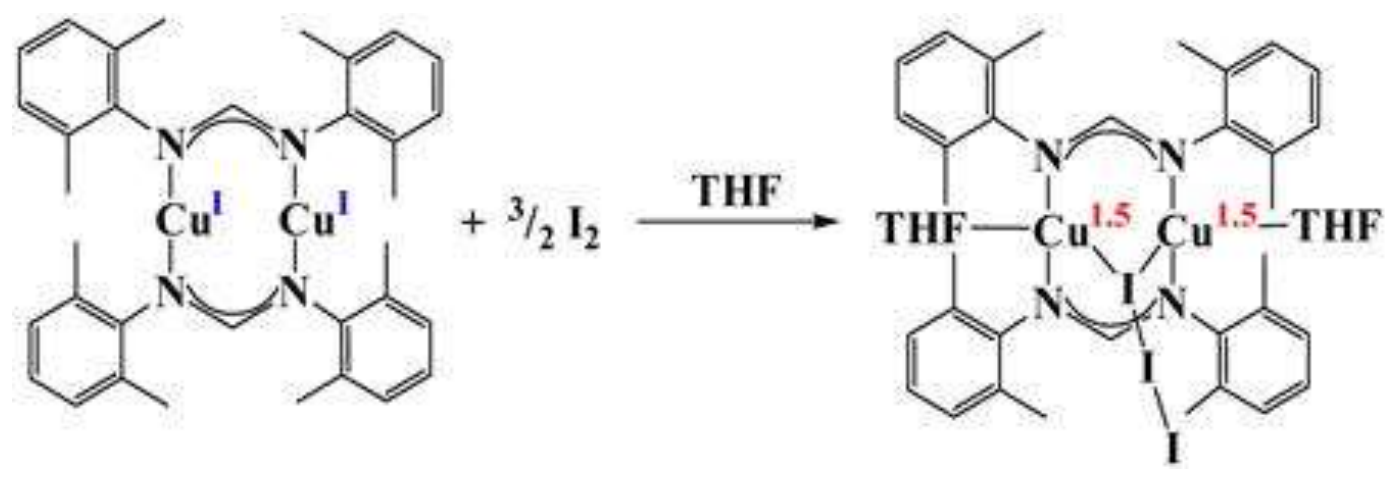

The structure of $\mathbf{2}$, Figure 2, shows a similar structure to the parent compound, $\mathbf{1}$, with each $\mathrm{Cu}$ coordinated to the nitrogen of the same amidinate ligand. The Cu1-N1 and Cu1-N4 bond distances of 1.915(4) and 1.916(4) $\AA$ are slightly longer than the 1.904(4) and 
1.910(4) $\AA$ lengths of Cu2-N2 and Cu2-N3. The metal-metal bond is now 2.5103(9) $\AA$ which is shorter than 2.5477(14) $\AA$ in 1.

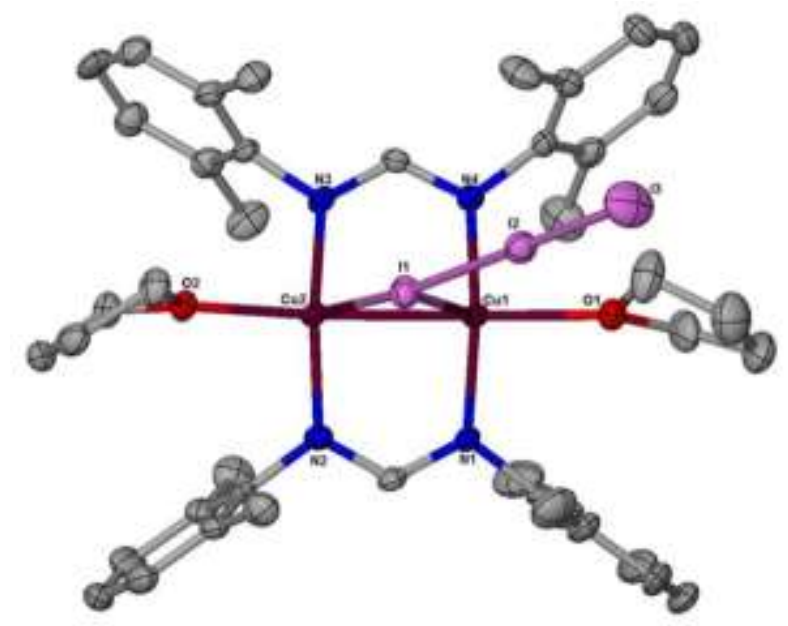

Fiqure 2. Molecular structure of 2•2THF with thermal ellipsoids projected at $50 \%$ probability level. Hydrogen atoms and solvent molecules have been omitted for clarity. Selected bond distances $(\AA)$ and angles $\left(^{\circ}\right)$ : Cu1-N1: 1.915(4); Cu1-N4: 1.916(4); Cu1-I1: 2.9991(9); Cu1-O1: 2.167(4); Cu1-Cu2: 2.5103(9); Cu2-N2: 1.904(4); Cu2N3: 1.910(4); Cu2-O2: 2.127(4); Cu1-I1-Cu2: 48.458(18); N1-Cu1-N4: 159.1(2); N1-Cu1-O1: 94.52(17); N3-Cu2-N2: 160.58(19); N2-Cu2-O2: 94.82(17).

One remarkable feature of $\mathbf{2}$ is the bridging triiodide ligand as we can find no previous reports of this common counteranion behaving as an $\eta^{1}$-bridging ligand between two metal centers. Reports of $\mathrm{I}_{3}{ }^{-}$as a terminal ${ }^{64-70}$ and bridging ligand have been described but with one metal bound $\eta^{1}$ to both terminal iodine atoms. $\underline{71,72}$ The absorption at $530 \mathrm{~nm}$ is attributed to a metal to ligand charge transfer band. The solid-state Raman spectrum of $\mathbf{2}$ gave absorption at $168 \mathrm{~cm}^{-1}$, indicative of the triiodide ligand, Figure S2.

The electronic structure of $\mathbf{2}$ was probed using EPR spectroscopy. The X-band spectrum of $\mathbf{2}$, Figure 3 , is well-resolved about the high field $g$-value, $g_{\mathrm{z}}$, where $A_{z}=78 \mathrm{G}$ in a $1: 2: 3: 4: 3: 2: 1$ pattern, where the last four lines are separated from the rest of the spectrum, and the intensities of the last four high field lines fit the pattern. The $1^{\text {st }}$ harmonic spectrum, Figure 3, emphasizes some of the low field lines. A well fit spectral simulation gives insight to the EPR parameters. To confirm that the $g_{\mathrm{z}}$-value is centered in the middle of the 7-line pattern for a dinuclear copper species and not a 10-line pattern for a trinuclear copper complex, the $g$-values, 2.209, 2.158, and 2.053 , were obtained at Q-band, $34.81 \mathrm{GHz}$, where the g-values permission has been granted for this version to appear in e-Publications@Marquette. American Chemical Society does not grant permission for this article to be further copied/distributed or hosted elsewhere without the express permission from American Chemical Society. 
are better separated (Figure S3). This confirms that the $g$-value on the high field side is a 7-line pattern due to a mixed-valence dinuclear $2 \mathrm{Cu}(1.5,1.5)$ complex. $\underline{73,74}$ Therefore $\mathbf{2}$ is a Class III species. $\underline{75}$ At lower microwave frequencies, the low field side of the spectrum is better resolved, but the $g_{z}$ region is less resolved than at X-band.

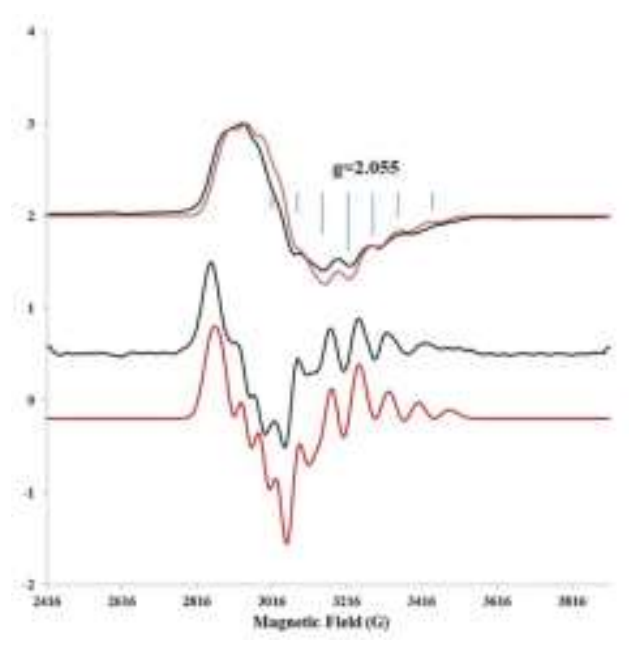

Fiqure 3. X-band spectrum of 2 in THF at $110 \mathrm{~K}$ : Exp (black traces, $1^{\text {st }}$ harmonic $2 \%$ Bessel); Sim (red traces) $g=2.220,2.170,2.055 ; A=120,140,218 \mathrm{MHz}$ (43, 50, 78 G); Iwpp 5 G, HStrain 160150 180, mwFreq 9.292 GHz.

The electronic structure and spectroscopic features of complex $\mathbf{2}$ were further probed using density functional theory (DFT). These calculations employed the hybrid B3LYP functional and the crystallographically-determined structure, although the methyl substituents of the phenyl rings were replaced with $\mathrm{H}$-atoms. The computed singly-occupied molecular orbital (SOMO), shown in Figure $\underline{4}$, is best described as the antibonding combination of the two $\mathrm{Cu}$ based $d\left(x^{2}-y^{2}\right)$ orbitals, consistent with the shortening of the $\mathrm{Cu}-\mathrm{Cu}$ interaction upon oxidation. The overall composition of the SOMO is $39 \%$ Cu1, 31\% Cu2, and 14\% $\mathrm{N}_{\text {amid, }}$ with only minor contributions from the THF (4\%) and $\mathrm{I}_{3}^{-}(2 \%)$ ligands. For reference, the estimated spin density distribution in the $\mathrm{Cu}_{\mathrm{A}}$ site has been calculated to be $38 \% . \underline{76}$ Thus, the unpaired electron is almost evenly de-localized over the two copper centers, also consistent with the assignment of $\mathbf{2}$ as a class III mixed-valence compound. 


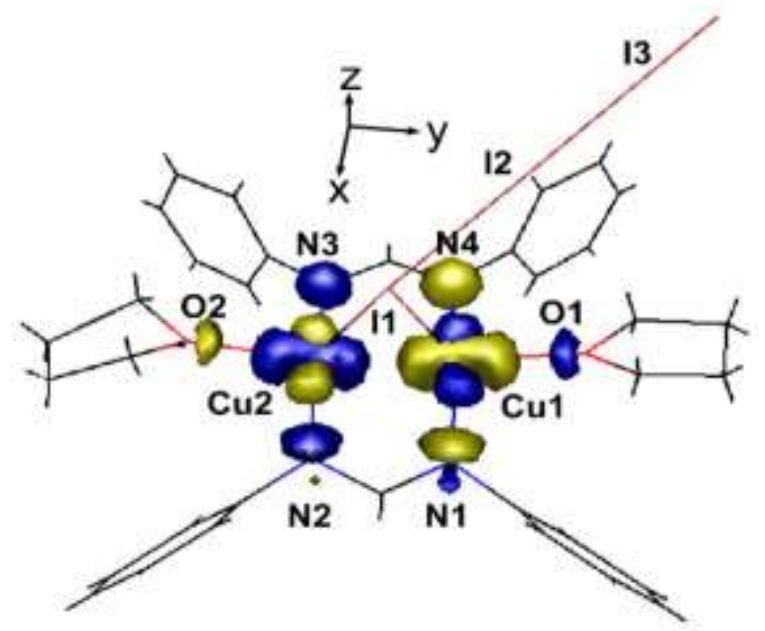

Figure 4. DFT-generated isosurface plot of the SOMO of complex 2. The orientation of the $\mathbf{g}$-tensor is indicated by the coordinate system; by convention, the $\mathrm{x}$-axis is assigned to $g_{\min }$ and the $z$-axis is assigned to $g_{\max }$.

As summarized in Table S1, the $g$-values of $2.200,2.152$, and 2.066 provided by DFT are quite close to the experimental values determined by EPR spectroscopy. We also computed hyperfine coupling values for the two $\mathrm{Cu}$ nuclei, and both $\mathbf{A}$-tensors feature large contributions from spin-dipolar and spin-orbit coupling terms. The ${ }^{63} \mathrm{Cu}$ A-tensors are not coincident with each other, or with the molecular $\mathbf{g -}$ tensor (Table S1). Therefore, it was necessary to simulate the predicted EPR spectrum using the Euler angles provided by the calculation, and the results are shown in Figure 5. Since the magnitudes of the computed $A$-values are approximately the same for the two nuclei, each EPR feature displays a seven-line pattern (although such splitting may not be resolved in the actual spectrum). In good agreement with the experimental data, DFT predicts a hyperfine splitting of $234 \mathrm{MHz}$ for the high-field $g_{\mathrm{x}}$ resonance and smaller $A$-values of 85 and $180 \mathrm{MHz}$ for the $g_{\mathrm{y}}$ and $g_{\mathrm{z}}$ features, respectively (Figure 5 ). Collectively, these DFT calculations nicely reproduce the distinctive spectroscopic features of complex $\mathbf{2}$. 
NOT THE PUBLISHED VERSION; this is the author's final, peer-reviewed manuscript. The published version may be accessed by following the link in the citation at the bottom of the page.

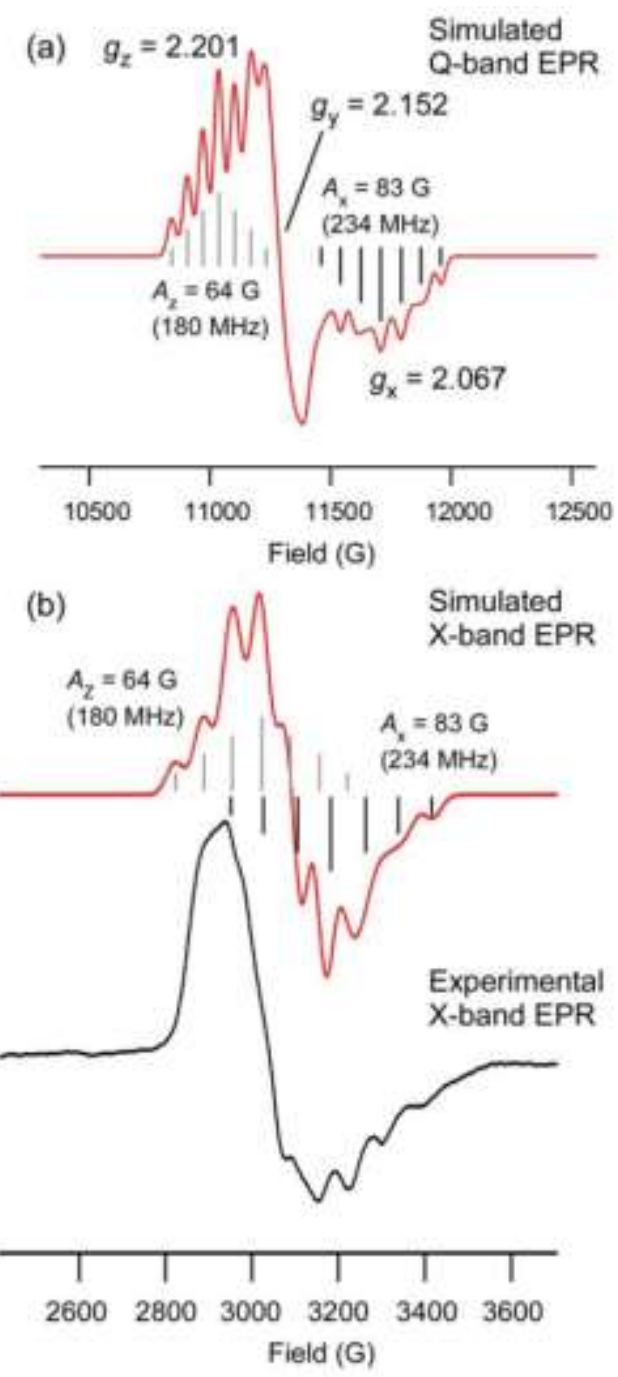

Figure 5. Simulated EPR spectra of complex 2 generated with DFT-calculated parameters. The microwave frequency employed in the simulations was either 34.0 $\mathrm{MHz}$ (a) or $9.28 \mathrm{MHz}$ (b). The experimental X-band EPR spectrum is shown at the bottom.

Performing the reaction of $\mathbf{1}$ with $\mathrm{I}_{2}$ in acetonitrile affords a dark red colored solution, eq 2. The UV-Vis-NIR spectrum of $\mathbf{3}$ (Figure S1) showed different absorptions to $\mathbf{2}$, indicating the formation of a new species. Complex $\mathbf{3}$ has one shoulder feature around $500 \mathrm{~nm}$ and two NIR absorptions at 860 and $1510 \mathrm{~nm}$. The feature at $860 \mathrm{~nm}$ is similar to that for the $\mathrm{Cu}_{\mathrm{A}}$ site at $808 \mathrm{~nm}$. $\underline{\text {.7 }}$ The absorption spectra of $\mathbf{2}$ and $\mathbf{3}$ were interpreted with the aid of time-dependent DFT (TD-DFT) calculations. For both complexes, the computed spectra (Figure S4) nicely reproduce the presence of broad features in the NIR region between 800 and $2000 \mathrm{~nm}$. DFT attributes these NIR bands to charge

Inorganic Chemistry, Vol 54, No. 17 (August 8, 2015): pg. 8509-8517. DOI. This article is @ American Chemical Society and permission has been granted for this version to appear in e-Publications@Marquette. American Chemical Society does not grant permission for this article to be further copied/distributed or hosted elsewhere without the express permission from American Chemical Society. 
transfer (CT) transitions from the $\mathrm{I}_{3}^{-}$(or $\mathrm{I}^{-}$) ligand to the $\left[\mathrm{Cu}_{2}\right]^{3+}$ unit. These bands are rather weak $\left(\varepsilon \sim 1000 \mathrm{M}^{-1} \mathrm{~cm}^{-1}\right)$ due to poor overlap between $\mathrm{I}_{3}^{-}$(or $\mathrm{I}^{-}$)-based orbitals and the $\mathrm{Cu}$-based SOMO. The intervalence CT transition is predicted by TD-DFT to occur at $466 \mathrm{~nm}$ for 2 and $475 \mathrm{~nm}$ for 3, corresponding to the experimentally-observed bands at 530 and $500 \mathrm{~nm}$, respectively. Unfortunately, these absorptions are obscured by visible transitions.

Dark red crystals were obtained from a saturated acetonitrile solution at $-25{ }^{\circ} \mathrm{C}$ and the structure was determined as $[(2,6-$ $\left.\left.\mathrm{Me}_{2} \mathrm{C}_{6} \mathrm{H}_{3} \mathrm{~N}\right)_{2} \mathrm{C}(\mathrm{H})\right]_{2} \mathrm{Cu}_{2}\left(\mu_{2}-\mathrm{I}\right)\left(\mathrm{NCCH}_{3}\right)_{2}, 3$, Figure 6. Complex 3, in analogy to $\mathbf{2}$, has coordinated solvent molecules, in this case acetonitrile. Interestingly, only an iodide remains that bridges each copper ion. In addition, the $\mathrm{Cu}-\mathrm{Cu}$ bond distance is 2.4810 (3) $\AA$, about $0.06 \AA$ decrease from 1 and $0.03 \AA$ from $\mathbf{2}$. The difference between $\mathbf{2}$ and $\mathbf{3}$ and a previously reported mixed-valence $\mathrm{Cu}(1.5,1.5)$ complex is in Lee's complex, $\left.\left\{\mathrm{Cu}_{2}\left[2,6-\mathrm{Me}_{2} \mathrm{C}_{6} \mathrm{H}_{3} \mathrm{~N}\right)_{2} \mathrm{C}(\mathrm{Ph})\right]_{2}\right\}^{+}$, $7 \mathrm{f}$ backbone carbon atom has a phenyl group in the amidinate ligand, $\mathbf{2}$ and $\mathbf{3}$ are neutral instead of cationic as well as contain triiodide or iodide. The molecular and electronic structure of $\mathbf{2}, \mathbf{3}$, and $\left.\left\{\mathrm{Cu}_{2}\left[2,6-\mathrm{Me}_{2} \mathrm{C}_{6} \mathrm{H}_{3} \mathrm{~N}\right)_{2} \mathrm{C}(\mathrm{Ph})\right]_{2}\right\}^{+}$ are similar in their bond metrics and similar spectroscopic features. The more sterically crowded amidinate complex bearing the phenyl group shows shorter $\mathrm{Cu}-\mathrm{Cu}$ bond distances of an average of 2.42(1) $\AA$ between two independent molecules in the unit cell for the THF adduct and 2.4571(2) $\AA$ between two independent molecules for the acetonitrile coordinated complex.

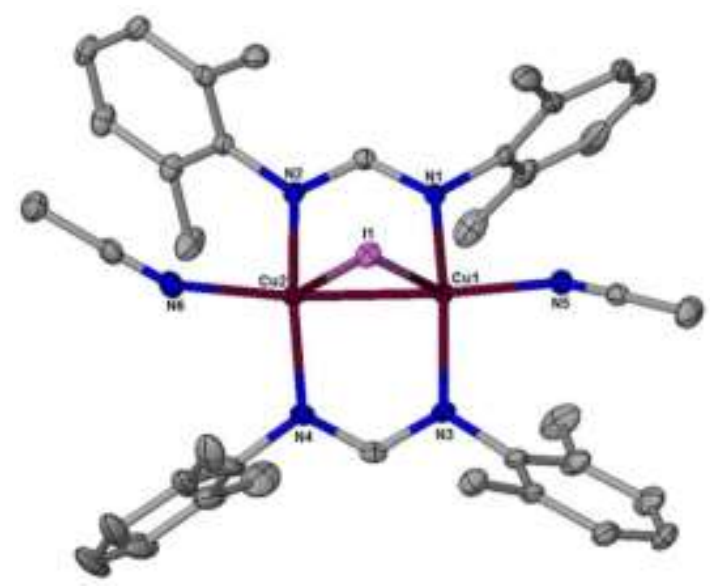

Fiqure 6. Molecular structure of 3 with thermal ellipsoids projected at $50 \%$ probability level. Hydrogen atoms have been omitted for clarity. Selected bond distances $(\AA)$ and permission has been granted for this version to appear in e-Publications@Marquette. American Chemical Society does not grant permission for this article to be further copied/distributed or hosted elsewhere without the express permission from American Chemical Society. 
angles $\left({ }^{\circ}\right)$ : Cu1-N1: 1.9257(15); Cu1-N3: 1.9409(15); Cu1-N5: 2.0533(16); Cu1-I1: 2.8276(3); Cu2-N2: 1.9475(15); Cu2-N4: 1.9387(15); Cu2-N6: 2.0790(17); Cu1Cu2: 2.4810(3); Cu1-I1-Cu2: 52.245(8); N1-Cu1-N3: 146.21(6); N3-Cu1-N5: 95.25(6); N2-Cu2-N4: 147.25(6); N4-Cu2-N6: 93.42(6).

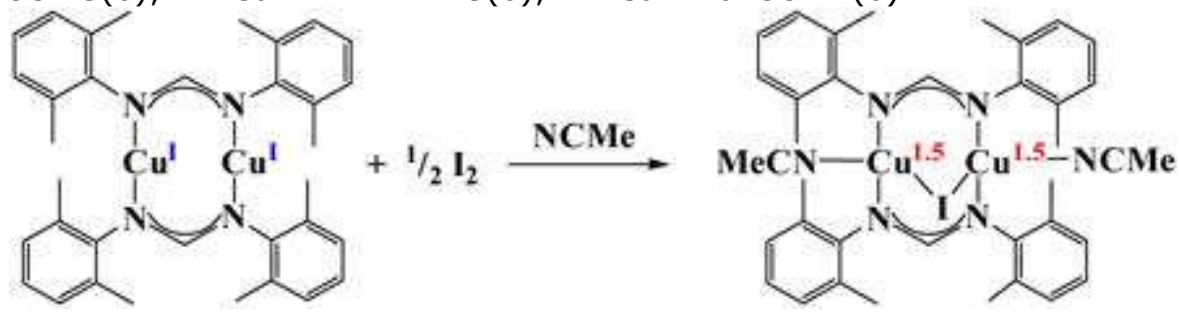

The X-band EPR spectrum for the reaction in acetonitrile, Figure

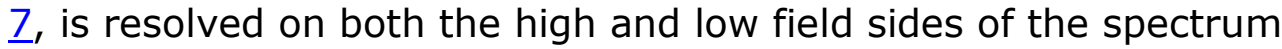
where a simulation of the spectrum and the $1^{\text {st }}$ harmonic (derivative) gives $g$-values of $2.23,2.14,2.04$ and $A$-values of $60,36,61 \mathrm{G}$.

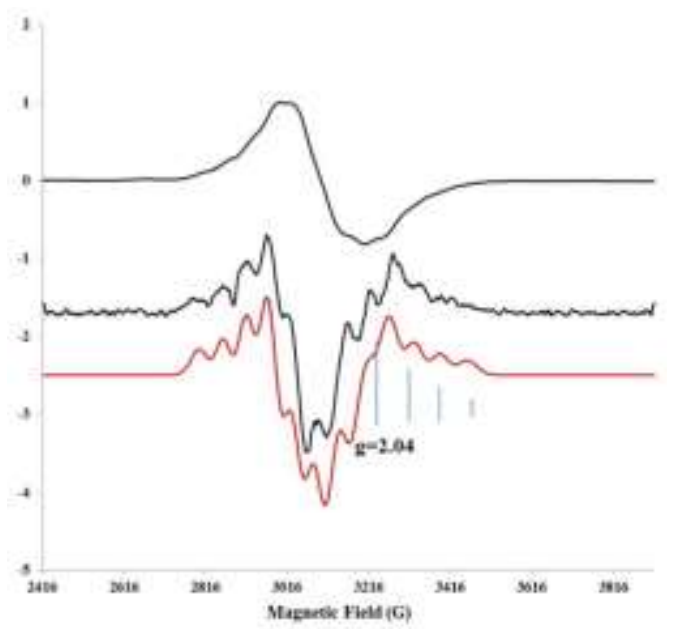

Figure 7. X-band spectrum of $\mathbf{3}$ in acetonitrile: Exp (black traces, $1^{\text {st }}$ harmonic $2 \%$ Bessel) mwFreq. $9.282 \mathrm{GHz}$, microwave power $16 \mathrm{~dB}(5 \mathrm{~mW}), 9$ scans, mod. Amp. 5G, temp. $110 \mathrm{~K}$; Sim (red trace): $g=2.23,2.14,2.04, A=167,100,170 \mathrm{MHz}(603661$ G), line width peak to peak 5 G, Hstrain 150200 170. Vertical lines indicate four of the seven line pattern on the high field side.

DFT calculations of complex 3 also converge to a class III mixed-valence ground state in which the unpaired spin density is fully delocalized over the two Cu centers. The composition of the SOMO is

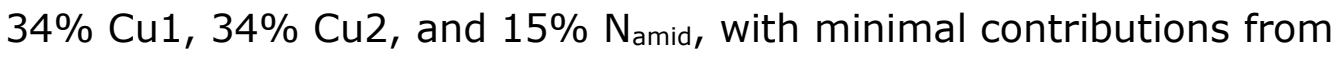
other moieties. The computed $g$-values of $2.187,2.151$, and 2.066 adequately mimic the experimental values, although DFT underestimates the rhombicity of the molecular $\mathbf{g}$-tensor. As in the case of complex 2, the A-tensors of the two Cu nuclei adopt different permission has been granted for this version to appear in e-Publications@Marquette. American Chemical Society does not grant permission for this article to be further copied/distributed or hosted elsewhere without the express permission from American Chemical Society. 
orientations than the $\mathbf{g}$-tensor, necessitating the use of Euler angles. The simulated EPR spectra, shown in Figure S5, exhibit hyperfine splittings of 160,60 , and $220 \mathrm{MHz}$ for $A_{x}, A_{y}$, and $A_{z}$, respectively. These values are consistent with the experimental EPR studies, which found large $A$-values of $\sim 170 \mathrm{MHz}$ in the high- and low-field features.

When the reaction of $\mathbf{1}$ with $\mathrm{I}_{2}$ is performed in toluene a dark purple-brown solution, eq 3 , was observed with only one absorbance at $495 \mathrm{~nm}$ in the visible region (Figure S1). The UV-Vis-NIR spectrum revealed two features in the visible region at 480 and $680 \mathrm{~nm}$ and no absorptions in the NIR region. Crystals suitable for $\mathrm{X}$-ray diffraction determined the structure as $\left[\left(2,6-\mathrm{Me}_{2} \mathrm{C}_{6} \mathrm{H}_{3} \mathrm{~N}\right)_{2} \mathrm{C}(\mathrm{H})\right]_{3} \mathrm{Cu}_{3}(\mathrm{I})_{2}, 4$, a trinuclear product, Figure 8. In this case, for a neutral complex there must be two $\mathrm{Cu}(\mathrm{II})$ ions and one $\mathrm{Cu}(\mathrm{I})$. This was also evidenced by an $S=1$ ground state as established using Evans' method.

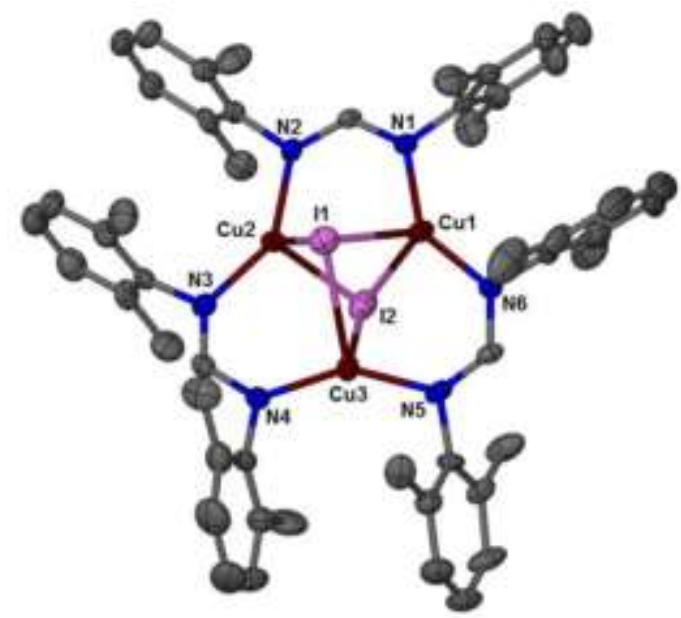

Figure 8. Molecular structure of $\mathbf{4} \cdot \mathbf{C}_{\mathbf{7}} \mathbf{H}_{\mathbf{8}}$ with thermal ellipsoids projected at $50 \%$ level. Hydrogen atoms and solvent molecule have been omitted for clarity. Selected bond distances $(\AA)$ and angles $\left({ }^{\circ}\right)$ : Cu1-N1: 1.927(5); Cu1-N6: 1.890(6); Cu2-N2: 1.912(5); Cu2-N3: 1.899(6); Cu3-N4: 1.909(6); Cu3-N5: 1.917(6); Cu1-I1:

2.6416(12); Cu2-I1: 2.7956(11); Cu3-I1: 3.0645(11); Cu1-I2: 2.9870(12); Cu2-I2: 2.6667(12); Cu3-I2: 2.8085(11); Cu1-I1-Cu2: 68.81(3); Cu1-I1-Cu3: 65.58(3); N1Cu1-N6: 141.3(2); N6-Cu1-I1: 106.97(18); N1-Cu1-I2: 95.01(18); N1-Cu1-I1: 101.94(18); N6-Cu1-I2: 103.46(18); I1-Cu1-I2: 101.88(3). 

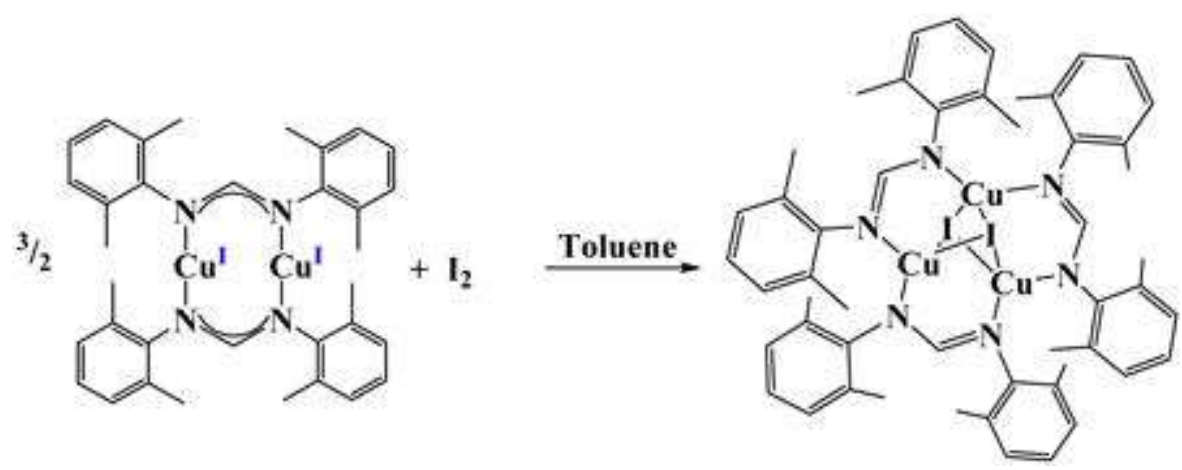

The structure of 4 resembles the mixed-valence $3 \mathrm{Cu}$ (II,III,III) complex isolated by the Stack group from $\mathrm{O}_{2}$ activation, however 4 contains iodide ions instead of oxo groups. $\frac{78}{}$ Each $\mathrm{Cu}$ ion is fourcoordinate in a pseudo-tetrahedral geometry consisting of two nitrogen atoms, one from a different amidinate as is seen in $\mathbf{1}$, and two individual iodide atoms. The N1-Cu1-N6 bond angle is more obtuse than an ideal tetrahedron at $141.3(2)^{\circ}$, however, the N1-Cu1-I1, N6Cu1-I2, and I1-Cu1-I2 angles are 101.94(18), 103.46(18), and $101.88(3)^{\circ}$, respectively. It should be noted the I1-I2 separation is $4.376 \AA$ so these are two distinct iodide ions. The $\mathrm{Cu}$-I bond distances showed those to Cu3 to be elongated at 3.0645(11) and 2.8085(11) $\AA$ compared to Cu1, 2.6416(12) and 2.9870(12) $\AA$, and Cu2, 2.7956(11) and 2.6667(12) $\AA$.

While the EPR spectrum for $\mathbf{2}$ and $\mathbf{3}$ were straight forward, the spectrum for $\mathbf{4}$ is complicated. Spectra were taken at different time intervals and the results varied with increasing time. In the first two hours, spectra appear similar to those found for 2, Figure 9 , with nicely resolved 7-line patterns indicating that the initial reaction of $\mathbf{1}$ with $\mathrm{I}_{2}$ in toluene also proceeds through a dinuclear, mixed-valence species. If the reaction is spiked with THF, $\mathbf{2}$ is obtained. Between two to eight hours, the spectrum changes to a trinuclear complex due to the presence of 10 -line pattern in the EPR spectrum, Figure 10. However, this is not the EPR spectrum of $\mathbf{4}$ as the spin-state is $S=1 / 2$ not 1 . The spectrum was simulated with $g$-values $2.212,2.148$ and 2.045. Some copper hyperfine is resolved for the middle $g$-value, but the best resolution is for the high-field $g$-value. The best resolved Qband spectrum for the intermediate leading to 4 in toluene, which is simulated with a 10 line pattern $(1: 3: 6: 10: 12: 12: 10: 6: 3: 1)$, has an $A_{x}$ 
value of $58 \mathrm{G}$, Figure 10 . The best resolved Q-band spectrum for an mixed-valence two copper intermediate leading to $\mathbf{4}$ in toluene, which is simulated with a 7 -line pattern $(1: 2: 3: 4: 3: 2: 1)$ has an $A_{x}$ value of $77 \mathrm{G}$, Figure $\mathrm{S6}$. The loss of resolution throughout the other spectra and the poorly resolved lines for $A_{z}$ are attributed to a mixture of dinuclear and trinuclear complexes having superimposed spectra. Finally, after eight hours, no EPR spectrum can be obtained and the complex is EPR silent.

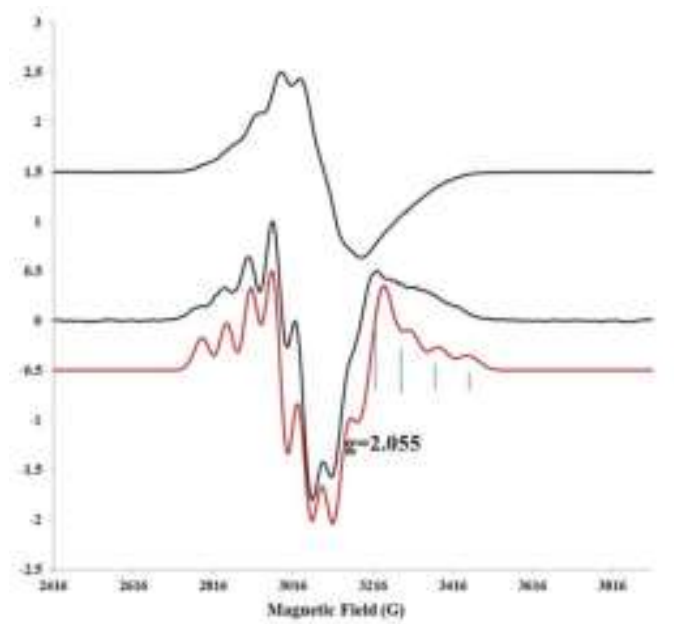

Fiqure 9. X-band EPR spectra in toluene of an intermediate preceding 4 indicative of two copper ions with $S=1 / 2$. Experimental spectra (black traces, $1^{\text {st }}$ harmonic $(2 \%$ Bessel); microwave freq $9.282 \mathrm{GHz}$; microwave power $16 \mathrm{~dB}(5 \mathrm{~mW}) ; 9$ scans, mod amp $5 \mathrm{~g}$; temp $110 \mathrm{~K}$; Simulation (red trace) $g=2.22,2.14,2.055 ; A=177,90,190$ $\mathrm{MHz}(63,32,68 \mathrm{G})$; line withdth peak to peak $5 \mathrm{G}$; HStrain 150200170 . Vertical lines indicate four of the seven line pattern for the high field $\mathrm{g}$ value.

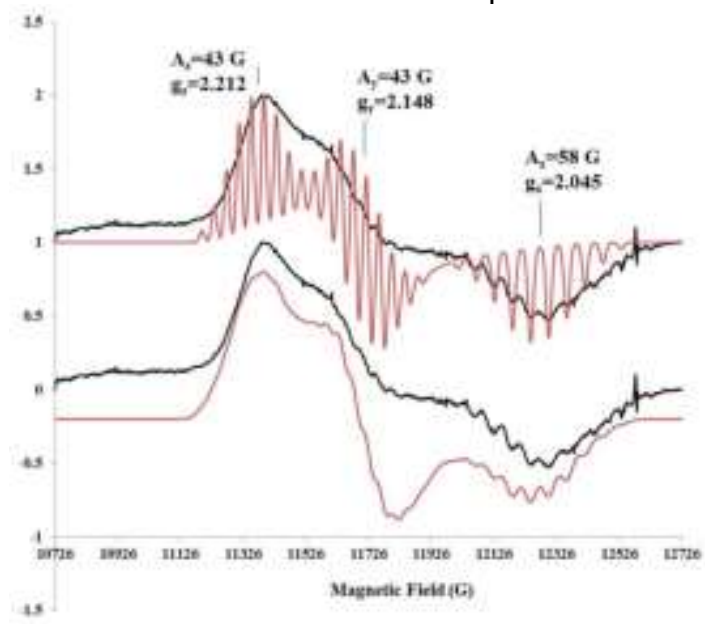

Figure 10. Q-band EPR spectrum in toluene of an intermediate three copper mixed valence compound preceding 4 indicating three copper centers with $S=1 / 2$. Experimental spectra (black traces), microwave frequency $34.768 \mathrm{GHz}$; temp $10 \mathrm{~K}$; 9 permission has been granted for this version to appear in e-Publications@Marquette. American Chemical Society does not grant permission for this article to be further copied/distributed or hosted elsewhere without the express permission from American Chemical Society. 
scans; mod amp $5 \mathrm{G}$; power $22 \mathrm{~dB}$; time constant $0.1 \mathrm{~s}$; scan time 2 min. Simulated spectra (red traces) HStrain 505050 (top); 150130150 (bottom).

While the mechanism of the formation of $\mathbf{4}$ is unknown, some deductions can be made from the EPR spectra. The EPR spectra, Figure $\underline{9}$ and Figure S3, in the first two hours has a similar spectra to $\mathbf{2}$ and $\mathbf{3}$ indicating that a dinuclear $2 \mathrm{Cu}(1.5,1.5)$ intermediate species is formed with a similar structure to $\mathbf{2}$ or $\mathbf{3}$. In THF or acetonitrile, those adducts flank each copper ion and provide the further electron density that is necessary to accommodate for the increased Lewis acidity of the copper upon oxidation. However, in toluene, the first intermediate complex that forms is similar but since solvent molecules are not available to coordinate to copper, the complex rearranges to form a trinuclear copper species but still only one reduction has taken place. This is supported by Figure 10. Once the intermediate trinuclear copper complex is assembled, the trinuclear, $S=1 / 2$ complex oxidizes a second time to produce 4 . This is outline in Scheme 1 . Since 4 is a non-Kramer state $(S=1), 4$ is EPR silent, presumably due to the large zero field splitting (ZFS).

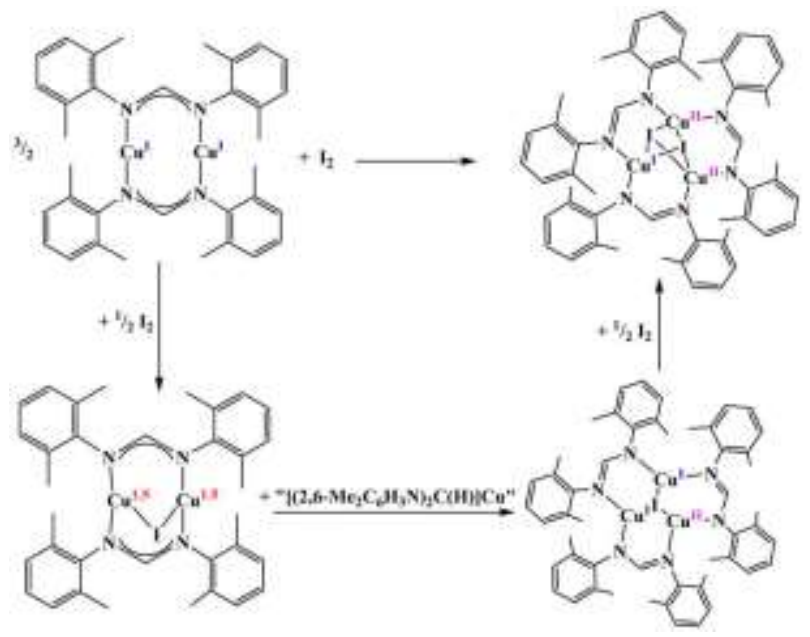

Scheme 1. Proposed formation of 4.

DFT calculations aided in the identification of oxidation states in the tricopper complex 4. These calculations employed the crystallographic structure and assumed an $S=1$ ground state. The SOMOs in complex 4 are strongly delocalized over the entire $\left[\mathrm{Cu}_{3} \mathrm{I}_{2}\right]^{3+}$ unit, making it difficult to assign oxidation states with confidence. However, the computed Mulliken spins indicate that Cu1 and Cu2 possess a sizable amount of unpaired spin density ( 0.36 and 0.48 permission has been granted for this version to appear in e-Publications@Marquette. American Chemical Society does not grant permission for this article to be further copied/distributed or hosted elsewhere without the express permission from American Chemical Society. 
spins, respectively), while substantially less spin density is localized on Cu3 (0.14 spins). It therefore appears that Cu1 and Cu2 are cupric $(+2)$, while Cu3 is the lone cuprous $(+1)$ ion. This conclusion is consistent with the relative $\mathrm{Cu}-\mathrm{I}$ bond lengths observed in the crystal structure. This is a rare example of a trinuclear copper complex with two cupric ions and one cuprous ion $\frac{79}{7}$ and the other $\mathrm{Cu}(\mathrm{I}, \mathrm{II}, \mathrm{II})$ compound was also EPR silent. In Tolman's Cu(I,II,I) compound, $\underline{80}$ an EPR spectrum could be achieved indicating a Class I species. The Murray group has recently reported a trinuclear copper complex which was also difficult to classify and it is possible that $\mathbf{4}$ has a similar electronic structure. $\underline{81}$

\section{Conclusion}

We have demonstrated the facile synthesis of mixed-valence $2 \mathrm{Cu}(1.5,1.5)$ complexes using a dinuclear $\mathrm{Cu}(\mathrm{I})$ amidinate starting material and $\mathrm{I}_{2}$ reduction. These complexes were each obtained using the same reaction conditions, except different solvents. In THF and acetonitrile, dinuclear products were obtained, $[(2,6-$ $\left.\left.\mathrm{Me}_{2} \mathrm{C}_{6} \mathrm{H}_{3} \mathrm{~N}\right)_{2} \mathrm{C}(\mathrm{H})\right]_{2} \mathrm{Cu}_{2}\left(\mu_{2}-\mathrm{I}_{3}\right)(\mathrm{THF})_{2}, 2$, and $[(2,6-$ $\left.\left.\mathrm{Me}_{2} \mathrm{C}_{6} \mathrm{H}_{3} \mathrm{~N}\right)_{2} \mathrm{C}(\mathrm{H})\right]_{2} \mathrm{Cu}_{2}\left(\mu_{2}-\mathrm{I}\right)\left(\mathrm{NCCH}_{3}\right)_{2}$, 3, respectively. However, in toluene, mixed-valence di- and trimetallic intermediate compounds were detected by EPR spectroscopy and a trinuclear compound, $[(2,6-$ $\left.\left.\mathrm{Me}_{2} \mathrm{C}_{6} \mathrm{H}_{3} \mathrm{~N}\right)_{2} \mathrm{C}(\mathrm{H})\right]_{3} \mathrm{Cu}_{3}\left(\mu_{3}-\mathrm{I}\right)_{2}$, 4, was isolated. Despite $\mathrm{I}_{2}$ not being a biologically relevant substrate with respect to copper-containing enzymes, the use of an inorganic substrate to gain insight into biomimetic chemistry has been demonstrated as these complexes represent isolable valence intermediates similar to those observed in copper-containing enzymes.

\section{Acknowledgments}

We gratefully acknowledge the University of Missouri College of Arts \& Sciences Alumni Faculty Incentive Grant as well as the Nuclear Forensics Education Award Program for startup funds (JRW). ATF thanks the National Science Foundation (CHE-1056845) for financial support. The EPR facilities are supported by the National Biomedical EPR Center Grant EB001980 from NIH. ACL was supported by a Howard Hughes Fellowship at the University of Missouri, Columbia. We 
NOT THE PUBLISHED VERSION; this is the author's final, peer-reviewed manuscript. The published version may be accessed by following the link in the citation at the bottom of the page.

thank Christian Reber, University of Montreal, for obtaining the Raman spectrum of 2.

\section{Footnotes}

Supporting Information. X-ray crystallographic data for complexes 2 4 have been deposited at the Cambridge Crystallographic Data Centre and EPR as well as UV-Vis-NIR and Raman spectroscopic data. This material is available free of charge via the Internet at http://pubs.acs.org.

\section{References}

${ }^{1}$ Rosenzweig AC, Sazinsky MH. Curr Opin Struct Biol. 2006;16:729.

2 Kroneck PM, Antholine WA, Riester J, Zumft WG. FEBS Letters. $1988 ; 242: 70$

${ }^{3}$ Brown K, Tegoni M, Prudencio M, Pereira AS, Besson S, Moura JJ, Moura I, Cambillau C. Nat Struct Mol Biol. 2000;7:191.

${ }^{4}$ Hwang HJ, Lu Y. Proc Natl Acad Sci. 2004;101:12842. [

${ }^{5}$ Gamelin DR, Randall DW, Hay MT, Houser RP, Mulder TC, Canters GW, de Vries S, Tolman WB, Lu Y, Solomon EI. J Am Chem Soc. $1998 ; 120: 5246$.

${ }^{6}$ Westmoreland TD, Wilcox DE, Baldwin MJ, Mims WB, Solomon EI. J Am Chem Soc. 1989;111:6106.

7 Harding C, McKee V, Nelson J. J Am Chem Soc. 1991;113:9684.

8 Barr ME, Smith PH, Antholine WE, Spencer B. J Chem Soc, Chem Commun. 1993: 1649.

9 Harding C, Nelson J, Symons MCR, Wyatt J. J Chem Soc, Chem Commun. 1994:2499.

10 Houser RP, Young VG, Tolman WB. J Am Chem Soc. 1996;118:2101.

${ }^{11}$ Breeze SR, Wang S. Inorg Chem. 1996;35:3404.

12 Setsune JI, Yokoyama T, Muraoka S, Huang HW, Sakurai T. Angew Chem, Int Ed. 2000;39:1115.

13 Zhang XM, Tong ML, Chen XM. Angew Chem, Int Ed. 2002;41:1029.

${ }^{14}$ Dong G, Chun-qi Q, Chun-ying D, Ke-liang P, Qing-jin M. Inorg Chem. 2003;42:2024.

15 Mukherjee A, Nethaji M, Chakravarty AR. Angew Chem, Int Ed. 2004;43:87.

${ }^{16}$ Zhan SZ, Li W, Wang BM, Zhang RL, Kunag WF. J Coord Chem. 2007;60:2747.

${ }^{17}$ Solomon EI, Xie X, Dey A. Chem Soc Rev. 2008;37:623.

Inorganic Chemistry, Vol 54, No. 17 (August 8, 2015): pg. 8509-8517. DOI. This article is @ American Chemical Society and permission has been granted for this version to appear in e-Publications@Marquette. American Chemical Society does not grant permission for this article to be further copied/distributed or hosted elsewhere without the express permission from American Chemical Society. 
NOT THE PUBLISHED VERSION; this is the author's final, peer-reviewed manuscript. The published version may be accessed by following the link in the citation at the bottom of the page.

18 Mooibroek TJ, Aromí G, Quesada M, Roubeau O, Gamez P, DeBeer George $\mathrm{S}$, van Slageren J, Yasin S, Ruiz E, Reedijk J. Inorg Chem. 2009;48:10643.

19 Torelli S, Orio M, Pécaut J, Jamet H, Le Pape L, Ménage S. Angew Chem, Int Ed. 2010;49:8249.

${ }^{20}$ Bakhoda A, Safari N, Amani V, Khavasi HR, Gheidi M. Polyhedron. 2011;30:2950.

${ }^{21}$ Kirillov AM, Filipowicz M, Guedes da Silva MFC, Kłak J, Smoleński P, Pombeiro AJL. Organometallics. 2012;31:7921.

22 Majouga AG, Beloglazkina EK, Moiseeva AA, Shilova OV, Manzheliy EA, Lebedeva MA, Davies ES, Khlobystov AN, Zyk NV. Dalton Trans. 2013;42:6290.

23 Gagne RR, Koval CA, Smith TJ, Cimolino MC. J Am Chem Soc. $1979 ; 101: 4571$.

${ }^{24}$ Gagne RR, Henling LM, Kistenmacher TJ. Inorg Chem. 1980;19:1226.

${ }^{25}$ Karlin DK, Gan Q-f, Tyeklar Z. Chem Commun. 1999:2295.

${ }^{26}$ LeCloux DD, Davydov R, Lippard SJ. Inorg Chem. 1998;37:6810.

${ }^{27}$ He C, Lippard SJ. Inorg Chem. 2000;39:5225.

${ }^{28}$ Gupta R, Zhang ZH, Powell D, Hendrich MP, Borovik AS. Inorg Chem. 2002;41:5100.

${ }^{29}$ Hagadorn JR, Zahn TI, Que JL, Tolman WB. Dalton Trans. 2003:1790.

30 Jiang X, Bollinger JC, Baik M-H, Lee D. Chem Commun. 2005:1043.

${ }^{31}$ Mankad NP, Antholine WE, Szilagyi RK, Peters JC. J Am Chem Soc. 2009; $131: 3878$.

32 Yang L, Powell DR, Klein EL, Grohmann A, Houser RP. Inorg Chem. 2007;46:6831.

${ }^{33}$ Lo SMF, Chui SSY, Shek L-Y, Lin Z, Zhang XX, Wen G-h, Williams ID. J Am Chem Soc. 2000;122:6293.

${ }^{34}$ Zhu Y, Wang W-y, Guo M-w, Li G, Lu H-j. Inorg Chem Commun. $2011 ; 14: 1432$.

${ }^{35}$ Kyung Ho Kim TU, Okubo Takashi, Hayami Shinya, Anma Haruho, Kato Kazuya, Shimizu Tetsuya, Fujimori Jyunji, Maekawa Masahiko, KurodaSowa Takayoshi. Chem Lett. 2011;40:1184.

${ }^{36}$ van Albada GA, Mutikainen I, Ghazzali M, Al-Farhan K, Reedijk J. Dalton Trans. 2012;41:4566.

37 Lewis EA, Tolman WB. Chem Rev. 2004;104:1047.

${ }^{38}$ Cramer CJ, Tolman WB. Acc Chem Res. 2007;40:601.

${ }^{39}$ Fukuzumi S, Tahsini L, Lee YM, Ohkubo K, Nam W, Karlin KD. J Am Chem Soc. 2012;134:7025.

${ }^{40}$ Cotton FA, Feng X, Matusz M, Poli R. J Am Chem Soc. 1988;110:7077.

${ }^{41}$ Lim BS, Rahtu A, Park JS, Gordon RG. Inorg Chem. 2003;42:7951.

42 Lane AC, Vollmer MV, Laber CH, Melgarejo DY, Chiarella GM, Fackler JP, Yang X, Baker GA, Walensky JR. Inorg Chem. 2014;53:11357.

Inorganic Chemistry, Vol 54, No. 17 (August 8, 2015): pg. 8509-8517. DOI. This article is @ American Chemical Society and permission has been granted for this version to appear in e-Publications@Marquette. American Chemical Society does not grant permission for this article to be further copied/distributed or hosted elsewhere without the express permission from American Chemical Society. 
NOT THE PUBLISHED VERSION; this is the author's final, peer-reviewed manuscript. The published version may be accessed by following the link in the citation at the bottom of the page.

${ }^{43}$ Apex II Suite. Bruker AXS Ltd; Madison, WS: 2006.

${ }^{44}$ BRUKER-NONIUS; APEXII. 4. Vol. 2008. Bruker-Nonius Inc; Madison, WI: 2008.

${ }^{45}$ Barbour LJ. J Supramol Chem. 2003;1:189.

${ }^{46}$ Stoll S, Schweiger A. J Magn Reson. 2006;178:42.

47 Neese F. 2.9 ed. Max Planck Institute for Chemical Energy Conversion; Muelheim, Germany: 2012.

48 Becke AD. J Chem Phys. 1993;98:5648.

${ }^{49}$ Lee CT, Yang WT, Parr RG. Phys Rev B. 1988;37:785.

${ }^{50}$ Schafer A, Horn H, Ahlrichs R. J Chem Phys. 1992;97:2571.

${ }^{51}$ Schafer A, Huber C, Ahlrichs R. J Phys Chem. 1994;5829:5829.

52 The "core properties" basis set is derived from the TurboMole DZ basis set developed by Ahlrichs and coworkers. It was obtained from the basis set library under ftp.chemie.uni-karlsruhe.de/pub/basen.

53 Neese F. J Chem Phys. 2001;115:11080.

${ }^{54}$ Neese F. J Chem Phys. 2003;118:3939.

55 Neese F. Curr Opin Chem Biol. 2003;7:125.

${ }^{56}$ Sinnecker S, Slep LD, Bill E, Neese F. Inorg Chem. 2005;44:2245.

57 Laaksonen L. J Mol Graph. 1992;10:33.

${ }^{58}$ Stratmann RE, Scuseria GE, Frisch MJ. J Chem Phys. 1998;109:8218.

${ }^{59}$ Casida ME, Jamorski C, Casida KC, Salahub DR. J Chem Phys. 1998; 108:4439.

${ }^{60}$ Bauernschmitt R, Ahlrichs R. Chem Phys Lett. 1996;256:454.

${ }^{61}$ Hirata S, Head-Gordon M. Chem Phys Lett. 1999;314:291.

62 Hirata S, Head-Gordon M. Chem Phys Lett. 1999;302:375.

${ }^{63}$ Abdou HE, Mohamed AA, Fackler JP. Inorg Chem. 2007;46:9692.

${ }^{64}$ Gossage RA, Ryabov AD, Spek AL, Stufkens DJ, van Beek JAM, van Eldik R, van Koten G. J Am Chem Soc. 1999;121:2488.

65 Zhao SB, Wang RY, Wang S. Inorg Chem. 2006;45:5830.

${ }^{66}$ Zhao SB, Wang RY, Wang S. Organometallics. 2009;28:2572.

${ }^{67}$ Sakow D, Baabe D, Böker B, Burghaus O, Funk M, Kleeberg C, Menzel D, Pietzonka C, Bröring M. Chem - Eur J. 2014;20:2913.

${ }^{68}$ Bowmaker GA, Di Nicola C, Pettinari C, Skelton BW, Somers N, White AH. Dalton Trans. 2011;40:5102.

${ }^{69}$ Blanchard S, Neese F, Bothe E, Bill E, Weyhermüller T, Wieghardt K. Inorg Chem. 2005;44:3636.

${ }^{70}$ Ditri TB, Carpenter AE, Ripatti DS, Moore CE, Rheingold AL, Figueroa JS. Inorg Chem. 2013;52:13216.

${ }^{71}$ Herrmann WA, Thiel WR, Herdtweck E. J Organomet Chem. 1988;353:323.

${ }^{72}$ Cunningham D, McArdle P, Mitchell M, NíChonchubhair N, O'Gara M, Franceschi F, Floriani C. Inorg Chem. 2000;39:1639.

Inorganic Chemistry, Vol 54, No. 17 (August 8, 2015): pg. 8509-8517. DOI. This article is @ American Chemical Society and permission has been granted for this version to appear in e-Publications@Marquette. American Chemical Society does not grant permission for this article to be further copied/distributed or hosted elsewhere without the express permission from American Chemical Society. 
NOT THE PUBLISHED VERSION; this is the author's final, peer-reviewed manuscript. The published version may be accessed by following the link in the citation at the bottom of the page.

73 Hay MT, Ang MC, Gamelin DR, Solomon EI, Antholine WE, Ralle M, Blackburn NJ, Massey PD, Wang X, Kwon AH, Lu Y. Inorg Chem. $1998 ; 37: 191$.

${ }^{74}$ Beinert H, Griffiths DE, Wharton DC, Sands RH. J Biol Chem. $1962 ; 237: 2337$.

75 Robin MB, Day P. In: Advances in Inorganic Chemistry and Radiochemistry. Emeléus HJ, Sharpe AG, editors. Vol. 10. Academic Press; 1968. p. 247.

${ }^{76}$ Neese F, Zumft WG, Antholine WE, Kroneck PMH. J Am Chem Soc. 1996;118:8692.

${ }^{77}$ Iwata S, Ostermeier C, Ludwig B, Michel H. Nature. 1995;376:660.

${ }^{78}$ Cole AP, Root DE, Mukherjee P, Solomon EI, Stack TDP. Science. 1996;273:1848.

79 Biswas A, Saha R, Ghosh A. CrystEngComm. 2011;13:5342.

${ }^{80}$ Houser RP, Tolman WB. Inorg Chem. 1995;34:1632.

${ }^{81}$ Di Francesco GN, Gaillard A, Ghiviriga I, Abboud KA, Murray LJ. Inorg Chem. 2014;53:4647. 
NOT THE PUBLISHED VERSION; this is the author's final, peer-reviewed manuscript. The published version may be accessed by following the link in the citation at the bottom of the page.

\section{Supplementary Material}

\section{Supporting Information}

\section{Supporting Information for
Di- and Trinuclear Mixed-Valence Copper Amidinate Complexes from Reduction of Iodine

Andrew C. Lane, ${ }^{1}$ Charles L. Barnes, ${ }^{1}$ William E. Antholine, ${ }^{2 *}$ Adam T. Fiedler, ${ }^{3 *}$ and Justin R. Walensky ${ }^{1 *}$

${ }^{1}$ Department of Chemistry, University of Missouri, $601 \mathrm{~S}$. College Avenue, Columbia, Missouri 65211

2 Department of Biophysics, Medical College of Wisconsin, 8701 Watertown Plank Road, Milwaukee, Wisconsin 53226

3 Department of Chemistry, Marquette University, 535 North $14^{\text {th }}$ Street, Milwaukee, Wisconsin 53233

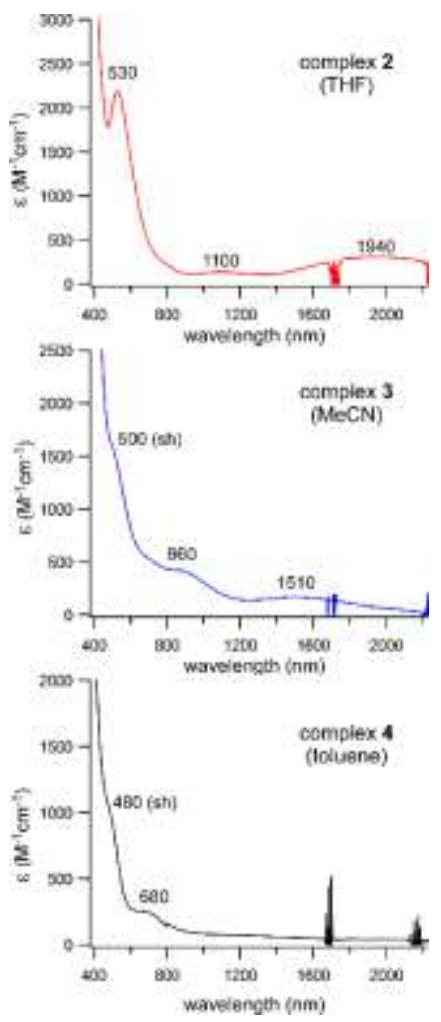

Figure S1. UV-Vis-NIR spectrum of 2, 3 and $\mathbf{4}$ in THF, $\mathrm{CH}_{3} \mathrm{CN}$, and toluene, respectively.

Inorganic Chemistry, Vol 54, No. 17 (August 8, 2015): pg. 8509-8517. DOI. This article is ( American Chemical Society and permission has been granted for this version to appear in e-Publications@Marquette. American Chemical Society does not grant permission for this article to be further copied/distributed or hosted elsewhere without the express permission from American Chemical Society. 
NOT THE PUBLISHED VERSION; this is the author's final, peer-reviewed manuscript. The published version may be accessed by following the link in the citation at the bottom of the page.

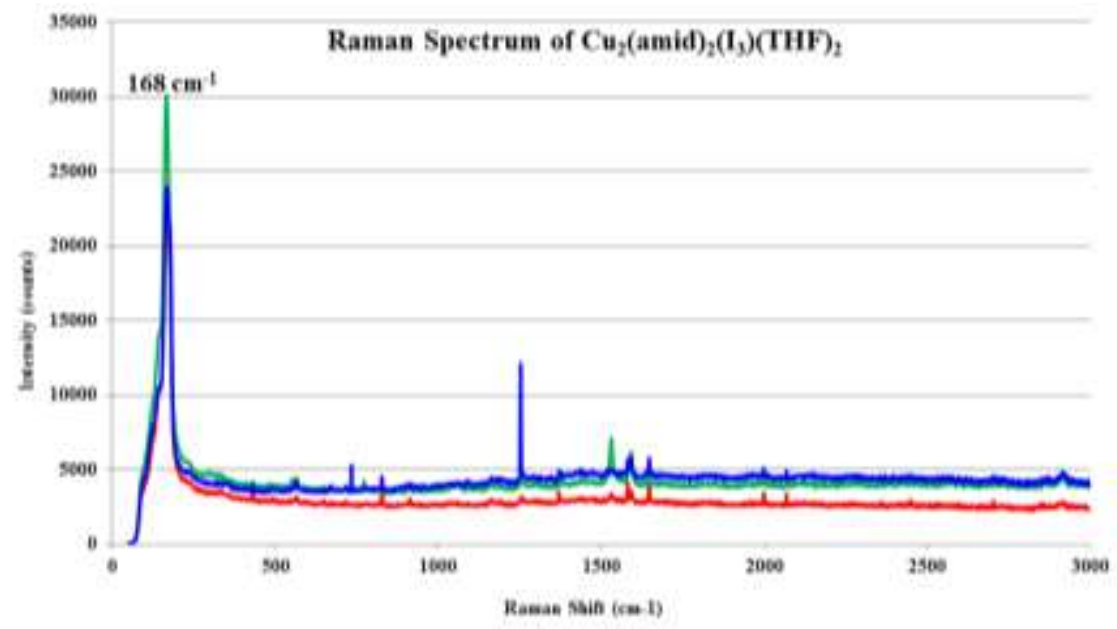

Figure S2. Raman spectrum of $\mathbf{2}$.

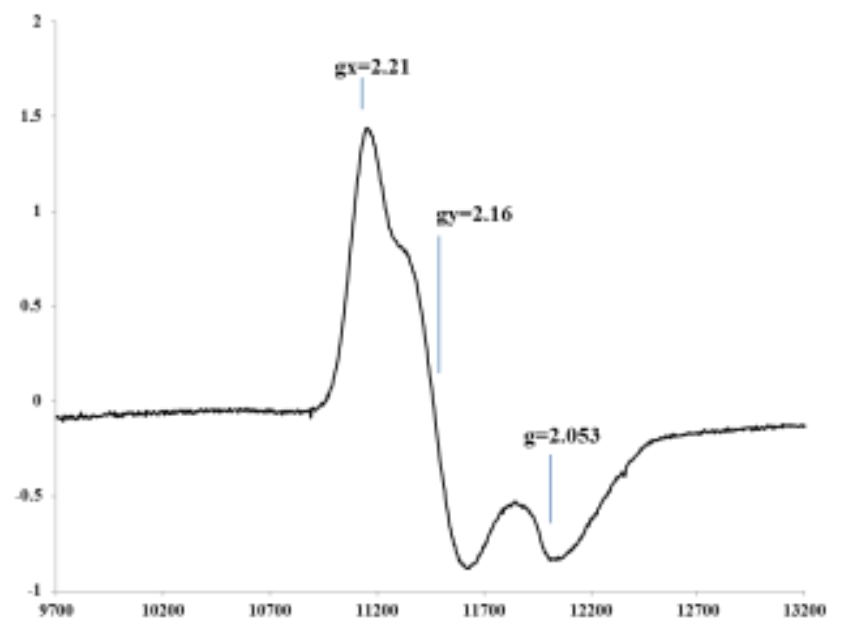

Figure S3. Q-band spectrum of 2: microwave freq $34.809 \mathrm{GHz}, 9$ scans, micro power $20 \mathrm{~dB}$, temp $-150^{\circ} \mathrm{C}$.

Table S1. Spin-Hamiltonian Parameters Calculated by DFT for Complexes 2 and $\mathbf{3}$.

\begin{tabular}{|l|c|c|}
\hline DFT-computed parameters & Complex 2 & Complex 3 \\
\hline$g_{\mathrm{x}}, g_{\mathrm{y}}, g_{\mathrm{z}}$ & $2.067,2.152,2.201$ & $2.066,2.151,2.187$ \\
\hline Cu1: $A_{\mathrm{x}}, A_{\mathrm{y}}, A_{\mathrm{z}}$ & $102,243,-202 \mathrm{MHz}$ & $-247,46,150 \mathrm{MHz}$ \\
\hline Euler angles: $\square, \square$, & $23.5^{\circ}, 7.1^{\circ}, 67.2^{\circ}$ & $-10.3^{\circ}, 88.8^{\circ},-2.1^{\circ}$ \\
\hline
\end{tabular}

Inorganic Chemistry, Vol 54, No. 17 (August 8, 2015): pg. 8509-8517. DOI. This article is ( American Chemical Society and permission has been granted for this version to appear in e-Publications@Marquette. American Chemical Society does not grant permission for this article to be further copied/distributed or hosted elsewhere without the express permission from American Chemical Society. 
NOT THE PUBLISHED VERSION; this is the author's final, peer-reviewed manuscript. The published version may be accessed by following the link in the citation at the bottom of the page.

\begin{tabular}{|l|l|l|}
\hline Cu2: $A_{x}, A_{y}, A_{z}(\mathrm{MHz})$ & $-205,81,157 \mathrm{MHz}$ & $72,166,-230 \mathrm{MHz}$ \\
\hline Euler angles: $\square, \square$, & $1.4^{\circ}, 89.2^{\circ}, 1.0^{\circ}$ & $-28.2^{\circ}, 3.2^{\circ},-64^{\circ}$ \\
\hline$\square$
\end{tabular}

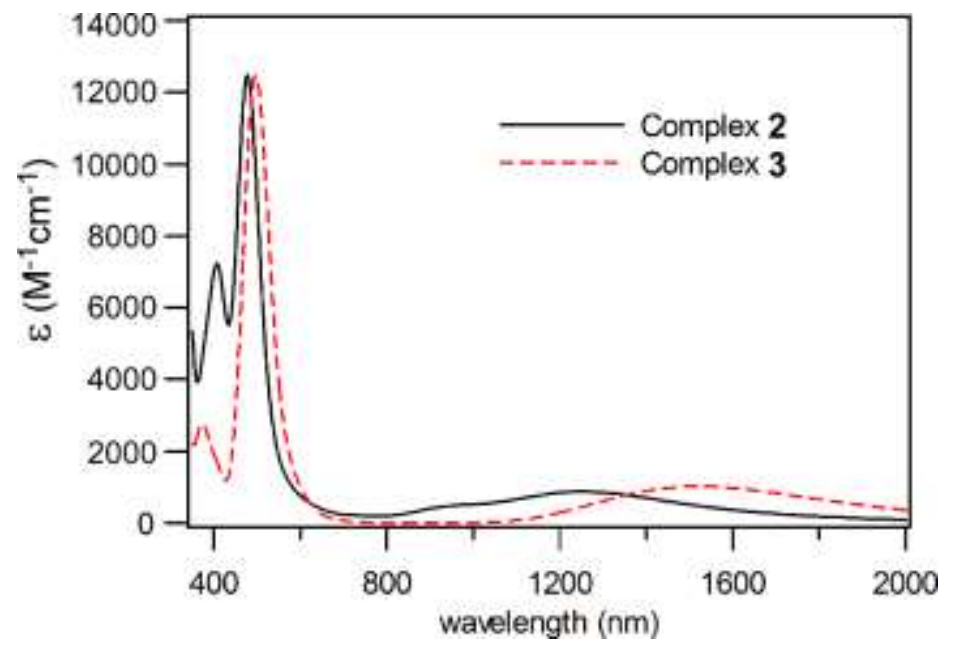

Figure S4. TD-DFT computed absorption spectra for complexes $\mathbf{2}$ and $\mathbf{3}$.
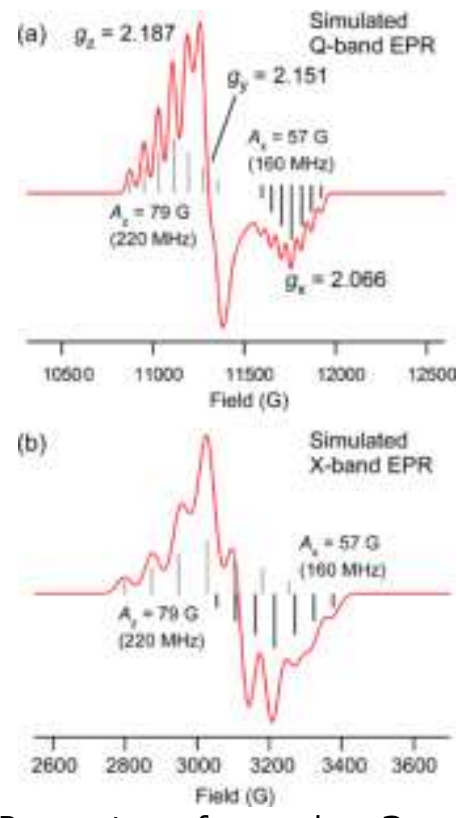

Figure S5. Simulated EPR spectra of complex 3 generated with DFT-calculated parameters. The microwave frequency employed in the simulations was either $34.0 \mathrm{MHz}$ (a) or $9.28 \mathrm{MHz}$ (b).

Inorganic Chemistry, Vol 54, No. 17 (August 8, 2015): pg. 8509-8517. DOI. This article is (c) American Chemical Society and permission has been granted for this version to appear in e-Publications@Marquette. American Chemical Society does not grant permission for this article to be further copied/distributed or hosted elsewhere without the express permission from American Chemical Society. 
NOT THE PUBLISHED VERSION; this is the author's final, peer-reviewed manuscript. The published version may be accessed by following the link in the citation at the bottom of the page.

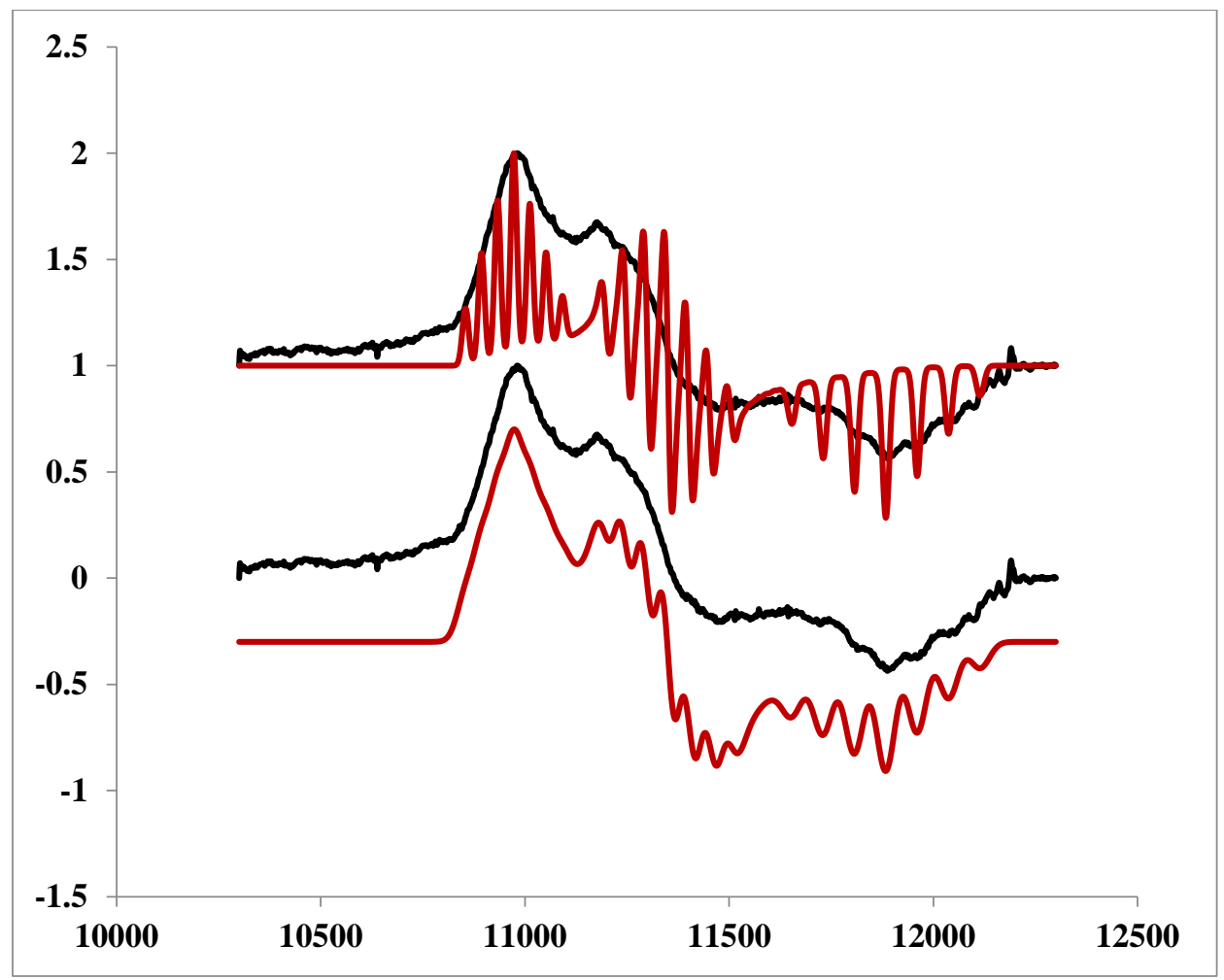

Figure S6. Q-band spectrum of an intermediate $2 \mathrm{Cu}$ complex preceding 4 indicating two copper centers with $S=1 / 2$. Experimental spectra(black traces), microwave frequency $34.901 \mathrm{GHz}, 140 \mathrm{~K}, 9$ scans, mod amp $5 \mathrm{G}$, power $22 \mathrm{~dB}$, time constant 0.1 $\mathrm{s}$, scan time $2 \mathrm{~min}$. Simulated spectra (red traces) $g=2.216,2.144,2.050, A=43,53$ 77 G, line width peak to peak 5 G, HStrain 505050 (top), 150130150 (bottom).

Inorganic Chemistry, Vol 54, No. 17 (August 8, 2015): pg. 8509-8517. DOI. This article is (c) American Chemical Society and permission has been granted for this version to appear in e-Publications@Marquette. American Chemical Society does not grant permission for this article to be further copied/distributed or hosted elsewhere without the express permission from American Chemical Society. 